\section{Chronic pain, associated factors, and impact on daily life: are there differences between the sexes?}

\author{
Dor crônica, fatores associados e influência na \\ vida diária: existe diferença entre os sexos?
}

1 Universidade Federal do
Maranhão, São Luís, Brasil.
2 Secretaria Municipal de
Saúde, São Luís, Brasil.
Correspondence
E. B. M. Vieira
Universidade Federal do
Maranhão.
Av. Bahia, Condomínio Gram
Village Turú III Chácara
Brasil-Turú, São Luís, MA
65065-770, Brasil.
enfermeira_erica@yahoo.
com.br

Abstract

This pioneering cross-sectional study in São Luís, Maranhão State, Brazil, aimed to compare men and women with chronic pain by identifying associated factors and characterizing the pain and its impact on daily life. Considering an expected prevalence of 25\%, 95\% confidence interval, and $3 \%$ precision, a cluster sample of 1,597 individuals was selected. The descriptive analysis showed a predominance of women, age bracket of 18 to 29 years, and brown skin color. Prevalence of chronic pain was higher in women than in men. Risk factors were analyzed with logistic regression. Increasing age was an associated risk factor for chronic pain in both sexes. In women, 12 or more years of schooling were associated with lower prevalence of chronic pain, and divorce or widowhood was associated with higher prevalence. Lower back pain and headache were the two most frequently reported sites. There was no difference between the sexes in time since onset or intensity of pain. Chronic pain had a greater impact on daily life for women and generated more feelings of sadness.

Chronic Pain; Chronic Disease; Sex Characteristics
Érica Brandão de Moraes Vieira 1,2 João Batista Santos Garcia 1 Antônio Augusto Moura da Silva 1 Rayanne Luíza Tajra Mualen Araújo 1 Ricardo Clayton Silva Jansen 1 Adriana Leite Xavier Bertrand 1

\section{Introduction}

Chronic pain is constant or intermittent pain that persists for a certain period of time and cannot be attributed to a specific cause 1,2 . It is currently a public health problem with high costs for health services. Chronic pain is associated with a twofold increase in hospitalization and medical consultations. Persons with chronic pain use emergency services five times more than those without chronic pain ${ }^{3,4}$.

According to a review study, prevalence of chronic pain varies from $12 \%$ to $80 \% 5$. This variation in prevalence reflects heterogeneous samples, criteria for time of onset of chronic pain, and different educational levels 6 . Cross-sectional studies suggest that increases in chronic pain are associated mainly with female gender, aging, and low socioeconomic status 7 . Although most studies found an association between increased pain and female gender 7,8,9,10,11, few epidemiological studies have compared how men and women experience pain 7,12,13.

Research has shown that when men and women suffer the same painful condition, women report greater frequency, intensity, and duration of the pain 12,14. The relationship between gender and pain is not simple, and many studies have attempted to discover the reasons for differences in the perception of pain between women and men 13,14,15,16,17. Some evidence suggests that endogenous and exogenous differences in 
the modulation of pain vary between men and women. However, the underlying mechanisms in these differences have still not been entirely elucidated 18.

From the psychosocial point of view, differences in the perception of pain are often attributed to the effects of stereotyped sexual roles 18 . From a more biological perspective, hormonal factors differ between the sexes and influence the perception of pain in men and women 18,19 . Some authors 15 contend that differences between the sexes are not limited to genetic and hormonal factors or social roles, but that there is a complex interaction between individual factors that requires more in-depth understanding.

Due to strong public health interests, most epidemiological studies on pain come from Europe and particularly from the Scandinavian countries 18. In 2008, the International Association for the Study of Pain (IASP) announced the Global Year against Pain in Women and encouraged research related to the theme. Due to the gap in knowledge on pain, especially in developing countries, a recent consensus report recommended research on gender, sex, and pain 20. In Brazil, there are few studies on the epidemiology of chronic pain 21,22 , and none focused on the experience of pain comparing men and women.

Establishing the prevalence of chronic pain in the population becomes necessary for understanding its characteristics in men and women and planning health services for its prevention and treatment. Thus, the current study is the first of its kind in Northeast Brazil proposing to compare men and women with chronic pain through the identification of associated factors, characterization of the pain, and impact on daily life.

\section{Material and methods}

\section{Study design}

This was a cross-sectional, population-based study, part of a research project on prevalence of chronic pain in São Luís, Maranhão State, Brazil, in 2009-2010.

\section{Study size}

Expected prevalence of chronic pain was estimated at $25 \% 23$, with a $95 \%$ confidence interval (95\%CI) and $3 \%$ relative precision. The necessary sample size was calculated at 800 individuals. Considering that the study focused on factors associated with prevalence of chronic pain, the sample was increased to 1,620 adults. This sample size has $80 \%$ power to verify $6 \%$ differences in the prevalence of chronic pain, assuming a 5\% probability of type I error and $20 \%$ estimated prevalence of chronic pain in the reference categories.

\section{Study population and sampling}

The municipality of São Luís has a population of approximately 1 million. The target population included individuals of both sexes older than 18 years residing in the municipality of São Luís, selected by two-stage probabilistic cluster sampling. In the first stage, from the numerical list of 979 census tracts in São Luís, 30 tracts were selected. In each census tract, mapping was performed to demarcate sub-tracts, called "blocks".

In the second stage, individuals were selected based on the selection of blocks and corners, using census tract maps. The selected corner was considered the starting point for the collection. Starting at this corner, the team proceeded to data collection going clockwise around the block until completing 54 interviews. This sample was obtained in each of the 30 census tracts, totaling 1,620 persons.

\section{Study definitions}

The age variable was categorized by brackets starting at 18 years. Education was grouped in years of schooling. Marital status was divided into the categories married or living with partner, single, and divorced or widowed. Skin color was self-reported and classified according to the official use in the population censuses in Brazil.

Monthly income was classified as low (up to $\mathrm{R} \$ 1,090$ per month), middle ( $\mathrm{R} \$ 1,091$ to $\mathrm{R} \$ 3,270$ ), and high (more than R\$3,270). Employment status was classified as employed, retired or on leave, and unemployed.

Chronic pain was defined as pain lasting at least six months. Intensity of pain was assessed using the visual analog scale (VAS), varying from 0 to 10 . Zero was defined as "absence of pain", 1 to 4 as "mild", 5 to 7 as "moderate", and 8 to 10 as "intense pain" 24 .

\section{Statistical methods}

All the analyses used Stata 10.0 (Stata Corp., College Station, USA). Logistic regression was used for analysis of associated factors 25,26 . The dependent variable was presence of chronic pain. The theoretical model assumes that the following variables explain chronic pain: sex, age, skin color, schooling, income, marital status, and occupational status. The assumption is that female sex, older age, white skin color, low schooling, low income, not living with a spouse or partner, 
and being employed would be associated with increased prevalence of chronic pain.

A descriptive analysis was performed first, followed by logistic regression to verify associations between the variables. The adjusted model included variables with $\mathrm{p}<0.20$, proceeding to stepwise and backward elimination. The final regression model used a p-value $<0.10$. Estimates were corrected considering the complex sampling design, with the svy command from Stata 10.0.

Specific questions on pain were explored by applying the chi-square test to verify differences in prevalence between males and females, with statistical significance set at $\mathrm{p}<0.05$.

\section{Data collection instrument}

A 31-item questionnaire was used, with questions on socioeconomic characteristics and others related to chronic pain.

The team was trained to use the questionnaire, and all the procedures were performed according to a standardized approach. In compliance with Ruling 196/96 of the Brazilian National Health Council, the research project was approved by the local Ethics Research Committee, and all the participants signed a free and informed consent form.

\section{Results}

Out of the total sample of 1,620 individuals, 1,597 were interviewed, due to losses because of difficult access. Nearly two-thirds $(66.44 \%)$ were females. The majority were 18 to 29 years of age. The most frequent skin color was brown. Few had more than 11 years of schooling, and this proportion was higher in men than in women $(19.96 \%$ versus $15.55 \%)$. Mean income in the study population was predominantly low.

As for marital status, the majority were married or living with a partner. More women than men were widowed or divorced $(17.44 \%$ versus $8.02 \%)$. The majority were considered employed. There were many more unemployed women than men (43.07\% versus $22.57 \%$ ). Chronic pain was also more common in women $(49.39 \%$ versus $22.5 \%$ ) (Table 1 ).

Table 2 shows the unadjusted analysis for factors associated with chronic pain in women and men. Age was significantly associated with chronic pain. In women, increasing age was associated with higher prevalence of chronic pain ( $p<0.001$ ), while in men this increased prevalence only appeared after 50 years of age $(\mathrm{p}<$ $0.001)$. Skin color was not associated with pres- ence of chronic pain when comparing the sexes. There was a lower prevalence of chronic pain in women with more schooling $(\mathrm{p}<0.001)$.

Among females, there was a lower prevalence of chronic pain among persons with middle income $(p=0.013)$. Single marital status was associated with lower prevalence of chronic pain in both women and men $(\mathrm{p}<0.001)$. Analysis of employment status showed differences between men and women. Retired women and those on leave or unemployed showed a higher prevalence of chronic pain as compared to employed women $(\mathrm{p}<0.001)$. In men, prevalence of chronic pain was lower among the unemployed $(\mathrm{p}<0.001)$.

Table 3 showed the adjusted analysis for factors associated with chronic pain according to

\section{Table 1}

Overall characterization of the study sample, women and men. São Luís, Maranhão State, Brazil.

\begin{tabular}{|c|c|c|c|c|}
\hline \multirow[t]{2}{*}{ Variables } & \multicolumn{2}{|c|}{ Women } & \multicolumn{2}{|c|}{ Men } \\
\hline & $\mathbf{n}$ & $\%$ & $\mathbf{n}$ & $\%$ \\
\hline \multicolumn{5}{|l|}{ Age (years) } \\
\hline $18-29$ & 381 & 35.91 & 191 & 35.63 \\
\hline $30-39$ & 213 & 20.08 & 122 & 22.76 \\
\hline $40-49$ & 179 & 16.87 & 79 & 14.74 \\
\hline$\geq 50$ & 288 & 27.14 & 144 & 26.87 \\
\hline \multicolumn{5}{|l|}{ Skin color } \\
\hline Brown & 536 & 50.52 & 267 & 49.82 \\
\hline White & 284 & 26.77 & 148 & 27.61 \\
\hline Black & 241 & 22.71 & 121 & 22.57 \\
\hline \multicolumn{5}{|l|}{ Schooling (years) } \\
\hline$<8$ & 364 & 34.31 & 153 & 28.55 \\
\hline $8-11$ & 532 & 50.14 & 276 & 51.49 \\
\hline$\geq 12$ & 165 & 15.55 & 107 & 19.96 \\
\hline \multicolumn{5}{|l|}{ Income (times minimum wage) } \\
\hline Low & 683 & 64.37 & 280 & 52.24 \\
\hline Middle & 268 & 25.26 & 183 & 34.14 \\
\hline High & 110 & 10.37 & 73 & 13.62 \\
\hline \multicolumn{5}{|l|}{ Marital status } \\
\hline Married/Living with partner & 509 & 47.97 & 300 & 55.97 \\
\hline Single & 367 & 34.59 & 193 & 36.01 \\
\hline Widowed/Divorced & 185 & 17.44 & 43 & 8.02 \\
\hline \multicolumn{5}{|l|}{ Occupational status } \\
\hline Employed & 458 & 43.17 & 328 & 61.19 \\
\hline Retired/On leave & 146 & 13.76 & 87 & 16.24 \\
\hline Unemployed & 457 & 43.07 & 121 & 22.57 \\
\hline \multicolumn{5}{|l|}{ Chronic pain } \\
\hline Yes & 524 & 49.39 & 152 & 22.50 \\
\hline No & 537 & 50.61 & 384 & 77.50 \\
\hline Total & 1,061 & 100.00 & 536 & 100.00 \\
\hline
\end{tabular}


Unadjusted analysis of factors associated with chronic pain in women and men. São Luís, Maranhão State, Brazil.

\begin{tabular}{|c|c|c|c|c|c|c|}
\hline \multirow[t]{2}{*}{ Variables } & \multicolumn{3}{|c|}{ Women } & \multicolumn{3}{|c|}{ Men } \\
\hline & OR & $95 \% \mathrm{Cl}$ & p-value & OR & $95 \% \mathrm{Cl}$ & $\mathrm{p}$-value \\
\hline Age (years) & & & $<0.001$ & & & 0.001 \\
\hline $18-29$ & 1.00 & & & 1.00 & & \\
\hline $30-39$ & 1.79 & $1.31-2.44$ & & 1.25 & $0.77-2.03$ & \\
\hline $40-49$ & 3.23 & $2.34-4.46$ & & 0.86 & $0.48-1.55$ & \\
\hline$\geq 50$ & 3.54 & $2.67-4.69$ & & 2.02 & $1.33-3.05$ & \\
\hline Skin color & & & 0.220 & & & 0.637 \\
\hline Brown & 1.00 & & & 1.00 & & \\
\hline White & 0.87 & $0.68-1.13$ & & 0.84 & $0.56-1.26$ & \\
\hline Black & 1.14 & $0.88-1.48$ & & 0.85 & $0.55-1.30$ & \\
\hline Schooling (years) & & & $<0.001$ & & & 0.174 \\
\hline$<8$ & 1.00 & & & 1.00 & & \\
\hline $8-11$ & 0.63 & $0.50-0.79$ & & 0.75 & $0.52-1.09$ & \\
\hline$\geq 12$ & 0.34 & $0.24-0.48$ & & 0.64 & $0.38-1.09$ & \\
\hline Income (times minimum wage) & & & 0.013 & & & 0.407 \\
\hline Low & 1.00 & & & 1.00 & & \\
\hline Middle & 0.71 & $0.56-0.91$ & & 1.27 & $0.89-1.72$ & \\
\hline High & 0.73 & $0.52-1.04$ & & 0.97 & $0.58-1.63$ & \\
\hline Marital status & & & $<0.001$ & & & $<0.001$ \\
\hline Married/Living with partner & 1.00 & & & 1.00 & & \\
\hline Single & 0.60 & $0.47-0.77$ & & 0.53 & $0.36-0.78$ & \\
\hline Divorced/Widowed & 2.38 & $1.76-3.20$ & & 0.31 & $0.16-0.61$ & \\
\hline Occupational status & & & $<0.001$ & & & $<0.001$ \\
\hline Employed & 1.00 & & & 1.00 & & \\
\hline Retired/On leave & 1.94 & $1.43-2.62$ & & 1.29 & $0.84-1.98$ & \\
\hline Unemployed & 1.54 & $1.22-2.95$ & & 0.42 & $0.27-0.65$ & \\
\hline
\end{tabular}

OR: odds ratio; $95 \% \mathrm{Cl}$ : $95 \%$ confidence interval.

sex. Age remained associated with chronic pain in both sexes, while in women the prevalence increased progressively until 49 years of age $(\mathrm{p}<$ 0.001). In men, increased prevalence of chronic pain only appeared after 50 years of age $(\mathrm{p}<0.001)$.

Schooling was only an associated factor in women, and those with 12 or more years of schooling showed a lower prevalence of chronic pain. Marital status was an associated factor in both sexes. Divorced or widowed women showed an increase in prevalence of chronic pain, while single men were less affected by chronic pain than married, divorced, or widowed men.

After adjusted analysis, employment status only remained associated with chronic pain in females. Unemployed women showed a higher prevalence of chronic pain as compared to other women $(\mathrm{OR}=1.76$; 95\%CI: 1.36-2.27; $\mathrm{p}<0.001)$.

As for the site of pain, women reported more headache $(40.46 \%)$, while men reported more lower back pain (39.47\%). The proportion of pain in the lower limbs was similar in women (36.83\%) and men (37.50\%). The least frequent sites of pain were upper limbs and the cervical and thoracic regions, with less than $25 \%$ in both sexes.

As for duration of chronic pain, regardless of sex the majority reported pain lasting from 6 months to 4 years. For frequency, daily pain was the most common $(43.42 \%$ in men and $45.42 \%$ in women), and there was no significant difference between the sexes $(p=0.252)$. Presence of pain at the time of the interview, regardless of the intensity, was more common in women than in men $(p=0.034)$. Peak intensity of pain and overall pain intensity showed similar results between women and men, with no statistical significance (Table 4).

Table 5 shows that the majority of women (59.54\%) and men (59.87\%) reported that they tolerated pain well. However, when asked whether 
Table 3

Adjusted analysis of factors associated with chronic pain in women and men. São Luís, Maranhão State, Brazil.

\begin{tabular}{|c|c|c|c|c|c|c|}
\hline \multirow[t]{2}{*}{ Variables } & \multicolumn{3}{|c|}{ Women } & \multicolumn{3}{|c|}{ Men } \\
\hline & OR & $95 \% \mathrm{Cl}$ & p-value & OR & $95 \% \mathrm{Cl}$ & $\mathrm{p}$-value \\
\hline Age (years) & & & $<0.001$ & & & 0.009 \\
\hline $18-29$ & 1.00 & & & 1.00 & & \\
\hline $30-39$ & 1.84 & $1.32-2.58$ & & 0.98 & $0.59-1.64$ & \\
\hline $40-49$ & 3.25 & $2.28-4.62$ & & 0.69 & $0.37-1.26$ & \\
\hline$\geq 50$ & 3.19 & $2.21-4.61$ & & 1.85 & $1.11-3.09$ & \\
\hline Schooling (years) & & & 0.001 & & & - \\
\hline$<8$ & 1.00 & & & - & - & \\
\hline $8-11$ & 0.96 & $0.74-1.24$ & & - & - & \\
\hline$\geq 12$ & 0.52 & $0.36-0.76$ & & - & - & \\
\hline Marital status & & & $<0.001$ & & & $<0.001$ \\
\hline Married/Living with partner & 1.00 & & & 1.00 & & \\
\hline Single & 0.83 & $0.63-1.09$ & & 0.62 & $0.41-0.95$ & \\
\hline Divorced/Widowed & 2.04 & $1.46-2.84$ & & 0.20 & $0.10-0.41$ & \\
\hline Occupational status & & & $<0.001$ & & & $<0.001$ \\
\hline Employed & 1.00 & & & 1.00 & & \\
\hline Retired/On leave & 0.85 & $0.58-1.24$ & & 1.06 & $0.62-1.82$ & \\
\hline Unemployed & 1.76 & $1.36-2.27$ & & 0.42 & $0.27-0.65$ & \\
\hline
\end{tabular}

OR: odds ratio; $95 \% \mathrm{Cl}$ : $95 \%$ confidence interval.

Table 4

Characterization of chronic pain in men and women. São Luís, Maranhão State, Brazil.

\begin{tabular}{|c|c|c|c|}
\hline Variables & $\begin{array}{c}\text { Men (N = 152; } 100.0 \%) \\
n(\%)\end{array}$ & $\begin{array}{c}\text { Women }(N=524 ; 100.0 \%) \\
n(\%)\end{array}$ & p-value \\
\hline Time since onset of pain & & & 0.043 \\
\hline 6 months to 4 years & $81(53.64)$ & $267(51.63)$ & \\
\hline 4 to 10 years & $47(31.13)$ & $130(21.18)$ & \\
\hline$>10$ years & $23(15.23)$ & $127(22.19)$ & \\
\hline Frequency of pain & & & 0.252 \\
\hline Daily & $66(43.42)$ & $238(45.42)$ & \\
\hline Weekly & $30(19.74)$ & 95 (18.13) & \\
\hline Monthly & $6(3.95)$ & $43(8.21)$ & \\
\hline Variable & 50 (32.89) & $148(28.24)$ & \\
\hline Pain at the time of interview & & & 0.034 \\
\hline Mild & $28(18.42)$ & $113(21.56)$ & \\
\hline Moderate & $11(7.24)$ & $75(14.31)$ & \\
\hline Intense & $6(3.95)$ & $30(5.73)$ & \\
\hline Absent & 107 (70.39) & $306(58.40)$ & \\
\hline Worst level of pain & & & 0.736 \\
\hline Mild & $16(10.53)$ & $46(8.78)$ & \\
\hline Moderate & $37(24.34)$ & $139(26.53)$ & \\
\hline Intense & $99(65.13)$ & $339(64.69)$ & \\
\hline Pain in the overall context & & & 0.612 \\
\hline Mild & 29 (19.08) & $111(21.18)$ & \\
\hline Moderate & $93(61.18)$ & $297(56.68)$ & \\
\hline Intense & 30 (19.74) & 116 (22.14) & \\
\hline
\end{tabular}

Note: chi-square test performed to verify differences in the prevalence of chronic pain between men and women. 
Influence of chronic pain on daily life for men and women. São Luís, Maranhão State, Brazil.

\begin{tabular}{|c|c|c|c|}
\hline Variables & $\begin{array}{c}\text { Men }(N=152 ; 100.0 \%) \\
n(\%)\end{array}$ & $\begin{array}{c}\text { Women }(\mathrm{N}=524 ; 100.0 \%) \\
n(\%)\end{array}$ & $\mathrm{p}$-value \\
\hline Tolerates pain & & & 0.878 \\
\hline Well & $91(59.87)$ & 312 (59.54) & \\
\hline Little & $42(27.63)$ & $153(29.29)$ & \\
\hline No longer tolerates & $19(12.50)$ & $59(11.27)$ & \\
\hline Impairments caused by pain & & & 0.011 \\
\hline Having fun & $5(3.29)$ & $36(6.87)$ & \\
\hline Working & $36(23.68)$ & $123(23.47)$ & \\
\hline Daily activities & $22(14.48)$ & $125(23.85)$ & \\
\hline Pain doesn't interfere & 89 (58.55) & $240(45.81)$ & \\
\hline Feeling of sadness & & & 0.011 \\
\hline Yes & $58(38.16)$ & $261(49.81)$ & \\
\hline No & $94(61.84)$ & $263(50.19)$ & \\
\hline Family believes in the pain & & & 0.175 \\
\hline Yes & $139(91.45)$ & $495(94.47)$ & \\
\hline No & $13(8.55)$ & $29(5.53)$ & \\
\hline Self-rated health & & & 0.031 \\
\hline Excellent & $7(4.60)$ & $13(2.48)$ & \\
\hline Very good & $10(6.58)$ & $27(5.15)$ & \\
\hline Good & $63(41.45)$ & 176 (33.59) & \\
\hline Fair & $51(33.55)$ & $251(47.90)$ & \\
\hline Bad & $21(13.82)$ & $57(10.88)$ & \\
\hline
\end{tabular}

Note: chi-square test performed to verify differences in the prevalence of chronic pain between men and women.

pain prevented them from doing anything, women reported having less fun, working less, and reducing their daily activities, while most men stated that the pain did not interfere in daily life $(\mathrm{p}=0.011)$.

Women also experienced more sadness because of pain $(p=0.011)$. When asked about their family support, more than $90 \%$ of women and men stated that their family members believed in the pain they felt. As for their health, $47.9 \%$ of the women rated it as fair while $41.45 \%$ of the men rated it as good $(\mathrm{p}=0.031)$.

\section{Discussion}

Prevalence of chronic pain in women was nearly $50 \%$, much higher than in men $(28.36 \%)$. This finding corroborates the majority of studies that compared prevalence of chronic pain between the sexes 9,21,27. In Spain, prevalence of chronic pain was $31.4 \%$ in women and $14.8 \%$ in men 27 . In Denmark, $22.4 \%$ of women reported suffering from chronic pain 9 . In France, the prevalence was
$28.2 \%$ in men and $35 \%$ in women 28 . Prevalence of chronic pain in our study in São Luís, especially in females, was high as compared to other epidemiological studies. However, variations in prevalence between the sexes involve geographic and especially cultural issues that differ between the study sites 13,18.

In this study, increasing age was associated with chronic pain in women, while among men the prevalence only increased after 50 years of age. Various authors have also shown changes in the prevalence of chronic pain with age 7,27,29. In Australia, prevalence of chronic pain increased with age and was higher in the various age groups among women as compared to men 10 . In Norway, there were no age-related differences between the sexes in association with chronic pain 12. In Hong Kong, there was a decline in the prevalence of chronic pain after 60 years 6 . The increase in chronic pain in older persons is known to be associated with the appearance of non-communicable illnesses and conditions 30 .

In the current study, increased schooling was associated with lower prevalence of chronic pain 
in women. Most other epidemiological studies have also found a lower prevalence of chronic pain among individuals with more schooling $7,8,9,10,11$. However, studies that specifically compared men and women and chronic pain found no differences between the sexes in relation to schooling 12,21 . In this study, the finding may have appeared because Brazilians with more schooling are better informed and enjoy better access to health services.

As for marital status, in women, divorce and widowhood were associated with higher prevalence of chronic pain, while among men, single individuals were more affected. Most studies have shown an association between increased risk of chronic pain and divorce 7,8,9. Sá et al. 21 also found a higher prevalence of chronic pain in divorced and widowed individuals and lower prevalence among single persons. In the case of women, divorce and widowhood involve social factors that may aggravate the appearance of chronic pain. For men, being single may mean caring more for one's health and thus experiencing less chronic pain.

Unemployed women showed a higher prevalence of chronic pain, while the opposite was true for men. Català et al. 27 found that unemployed persons, housewives, and retirees had a higher prevalence of chronic pain. Unemployment generates concerns in women, especially in relation to family stability, thereby exacerbating chronic pain. In men, a large share of chronic pain, especially lower back pain, is known to be work-related 31,32. This can explain the lower prevalence of chronic pain among unemployed males.

Sedentary lifestyle has been associated with an increase in chronic pain, and in this study it only increased the prevalence of chronic pain in women. According to one study, sedentary lifestyle was significantly greater in persons with chronic pain. Physical activity is known to be associated with physical and mental well-being and decreased risk of diseases. In addition, stretching and strengthening muscles can reduce chronic pain, especially in the lower back 33 .

Women in the current study were more likely to report headache, while men reported more back pain. A review study by Fillingin et al. 18 found increased prevalence of headache. Women in Hong Kong reported more painful sites than men, besides a higher percentage of headaches 6 . Miró et al. 34 also found that headache was signif- icantly more common in women. In Spain, headache was more common in women $(22.7 \%)$ and pain in the lower limbs more common in men (24.1\%). Hormonal factors related to the menstrual cycle are the main factor accounting for the high incidence of headache in women 14,18. In men, lower back pain is associated mainly with work activities 35 .

As for characterization of the pain, women reported more pain at the time of the interview when compared to men. In this study, impairments caused by pain were also more common in women, with major interference in their daily activities. A population-based study in Norway also found a higher intensity of pain at the moment of the interview among women ${ }^{12}$. Various studies found greater impact on daily activities among women ${ }^{6}$. Pain in women decreased their self-esteem, hindering their social contact. Pain appears to have less impact on daily life for men, because men are more acculturated to withstand problems and illnesses, including pain.

A feeling of sadness due to the pain was significantly more common in women than in men. Evidence also suggests that women with chronic pain experience more depression than men $6,18,27,34,36$. Women are more emotional and more readily display their feelings of sadness caused by pain. Due to social issues, men with chronic pain are less prone to show their feelings 37 . Depression was not investigated in this study, but it is important to highlight that feeling sad may signal the onset of a depressive state.

Some limitations were found in this study. The cross-sectional design does not allow identifying causality. However, the study's main focus was to verify the factors associated with chronic pain.

In short, prevalence of chronic pain in men and women in São Luís was high as compared to other studies. For women, older age and divorce or widowhood were factors associated with increased prevalence of chronic pain. In men, chronic pain was more prevalent from 50 years onward. As for specific issues related to chronic pain, some factors differed between women and men. At the time of the interview, more women than men reported pain. Because of the pain, women were more prone not to have fun or to perform their daily activities. Feeling sad was also more common in women. On average, men's selfrated health was good, and women's was fair. 


\section{Resumo}

Estudo transversal, pioneiro em São Luís, Maranhão, Brasil, com o objetivo de comparar homens e mulheres com dor crônica por meio da identificação dos fatores associados, caracterização da dor e influência na vida diária. Considerando a prevalência de 25\%, nível de 95\% de confiança e precisão de $3 \%$ foram entrevistadas 1.597 pessoas selecionadas por amostragem do tipo conglomerado. Na análise descritiva houve predomínio do sexo feminino, faixa etária entre 18 e 29 anos e cor parda. A prevalência de dor crônica foi maior nas mulheres em relação aos homens. Utilizou-se regressão logística para análise dos fatores de risco. Maior idade foi um fator associado à dor crônica em ambos os sexos. Nas mulheres, escolaridade a partir de 12 anos de estudos associou-se à menor prevalência, e estar divorciada/viúva e desempregada à maior prevalência de dor crônica. As regiões lombar e cefálica foram as mais referidas como locais de dor. Não houve diferença entre os sexos em relação ao tempo e intensidade dolorosa. A dor crônica teve maior influência na vida diária das mulheres e gerou mais sentimento de tristeza.

Dor Crônica; Doença Crônica; Características Sexuais

\section{Contributors}

E. B. M. Vieira contributed to the study design, data collection and analysis, and writing of the article. J. B. S. Garcia coordinated the project and contributed to the critical revision of the content and approval of the final version for publication. A. A. M. Silva contributed to the critical revision of the content, methodology, statistical analysis, and interpretation of the data. R. L. T. M. Araújo collaborated with the data collection and elaboration of the article. R. C. S. Jansen contributed to the study design and data collection and analysis. A. L. $\mathrm{X}$. Bertrand participated in the data analysis and critical revision of the content.

\section{Acknowledgments}

The authors wish to thank FAPEMA for grant no. APP 953RP9 and CNPq for grant no. 147693/2010-1.

\section{References}

1. Merskey H, Bogduk N. Classification of chronic pain: descriptions of chronic pain syndromes and definitions of pain terms. 2nd Ed. Seattle: IASP Press; 2004

2. Classification of chronic pain. Descriptions of chronic pain syndromes and definitions of pain terms. Prepared by the International Association for the Study of Pain, Subcommittee on Taxonomy. Pain Suppl 1986; 3:S1-226.

3. Blyth F, March L, Brnabic A, Cousins M. Chronic pain and frequent use of health care. Pain 2004; 111:51-8.

4. Blyth F. Chronic pain:is it a public health problem? Pain 2008; 137:465-6.

5. Abu-Saad Huijer H. Chronic pain: a review. J Med Liban 2010; 58:21-7.

6. Wong W, Fielding R. Prevalence and characteristics of chronic pain in the general population of Hong Kong. J Pain 2011; 12:236-45.
7. Blyth F, March L, Brnabic A, Jorm L, Williamson M, Cousins M. Chronic pain in Australia: a prevalence study. Pain 2001; 89:127-34.

8. Breivik H, Collett B, Ventafridda V, Cohen R, Gallacher D. Survey of chronic pain in Europe: prevalence, impact on daily life, and treatment. Eur J Pain 2006; 10:287-333.

9. Sjøgren P, Ekholm O, Peuckmann V, Grønbaek M. Epidemiology of chronic pain in Denmark: an update. Eur J Pain 2009; 13:287-92.

10. Currow D, Agar M, Plummer J, Blyth F, Abernethy A. Chronic pain in South Australia: population levels that interfere extremely with activities of daily living. Aust N Z J Public Health 2010; 34:232-9.

11. Johannes C, Le T, Zhou X, Johnston J, Dworkin R. The prevalence of chronic pain in United States adults: results of an internet-based survey. J Pain 2010; 11:1230-9. 
12. Rustøen T, Wahl A, Hanestad B, Lerdal A, Paul S, Miaskowski C. Gender differences in chronic pain: findings from a population-based study of Norwegian adults. Pain Manag Nurs 2004; 5:105-17.

13. Wiesenfeld-Hallin Z. Sex differences in pain perception. Gend Med 2005; 2:137-45.

14. Cairns BE, Gazerani P. Sex-related differences in pain. Maturitas 2009; 63:292-6.

15. Chin ML, Rosenquist R. Sex, gender, and pain: "men are from Mars, women are from Venus...". Anesth Analg 2008; 107:4-5.

16. Hurley RW, Adams MC. Sex, gender, and pain: an overview of a complex field. Anesth Analg 2008; 107:309-17.

17. Stutts L, McCulloch R, Chung K, Robinson M. Sex differences in prior pain experience. J Pain 2009; 10:1226-30.

18. Fillingim RB, King CD, Ribeiro-Dasilva MC, RahimWilliams B, Riley JL. Sex, gender, and pain: a review of recent clinical and experimental findings. J Pain 2009; 10:447-85.

19. Manson JE. Pain: sex differences and implications for treatment. Metabolism 2010; 59 Suppl 1:S16-20.

20. Greenspan JD, Craft RM, LeResche L, ArendtNielsen L, Berkley KJ, Fillingim RB, et al. Studying sex and gender differences in pain and analgesia: a consensus report. Pain 2007; 132 Suppl 1:S26-45.

21. Sá K, Baptista A, Matos M, Lessa I. Prevalence of chronic pain and associated factors in the population of Salvador, Bahia. Rev Saúde Pública 2009; 43:622-30.

22. Dellaroza MSG, Pimenta CAM, Matsuo T. Prevalência e caracterização da dor crônica em idosos não institucionalizados. Cad Saúde Pública 2007; 23:1151-60.

23. Harstall C, Ospina M. How prevalent is chronic pain? Pain Clinical Updates 2003; 11:1-4.

24. Price DD, McGrath PA, Rafii A, Buckingham B. The validation of visual analogue scales as ratio scale measures for chronic and experimental pain. Pain $1983 ; 17: 45-56$.

25. Pearce N. Effect measures in prevalence studies. Environ Health Perspect 2004; 112:1047-50.

26. Reichenheim ME, Coutinho ES. Measures and models for causal inference in cross-sectional studies: arguments for the appropriateness of the prevalence odds ratio and related logistic regression. BMC Med Res Methodol 2010; 10:66.
27. Català E, Reig E, Artés M, Aliaga L, López J, Segú J. Prevalence of pain in the Spanish population: telephone survey in 5000 homes. Eur J Pain 2002; 6:133-40.

28. Bouhassira D, Lantéri-Minet M, Attal N, Laurent B, Touboul C. Prevalence of chronic pain with neuropathic characteristics in the general population. Pain 2008; 136:380-7.

29. Rustøen T, Wahl A, Hanestad B, Lerdal A, Paul S, Miaskowski C. Age and the experience of chronic pain: differences in health and quality of life among younger, middle-aged, and older adults. Clin J Pain 2005; 21:513-23.

30. Mitchell C. Assessment and management of chronic pain in elderly people. Br J Nurs 2001; 10:296-304.

31. Silva MC, Fassa AG, Valle NCJ. Dor lombar crônica em uma população adulta do Sul do Brasil: prevalência e fatores associados. Cad Saúde Pública 2004; 20:377-85.

32. Jacobs J, Hammerman-Rozenberg R, Cohen A, Stessman J. Chronic back pain among the elderly: prevalence, associations, and predictors. Spine (Phila Pa 1976) 2006; 31:E203-7.

33. van den Berg-Emons RJ, Schasfoort FC, de Vos LA, Bussmann JB, Stam HJ. Impact of chronic pain on everyday physical activity. Eur J Pain 2007; 11: 587-93.

34. Miró J, Paredes S, Rull M, Queral R, Miralles R, Nieto R, et al. Pain in older adults: a prevalence study in the Mediterranean region of Catalonia. Eur J Pain 2007; 11:83-92.

35. Stubbs D, Krebs E, Bair M, Damush T, Wu J, Sutherland J, et al. Sex differences in pain and pain-related disability among primary care patients with chronic musculoskeletal pain. Pain Med 2010; 11:232-9.

36. Yu H, Tang F, Kuo B, Yu S. Prevalence, interference, and risk factors for chronic pain among Taiwanese community older people. Pain Manag Nurs 2006; 7:2-11.

37. Keogh E, Denford S. Sex differences in perceptions of pain coping strategy usage. Eur J Pain 2009; 13:629-34.

Submitted on 28/Apr/2011

Final version resubmitted on $03 / \mathrm{Jan} / 2012$

Approved on 13/Feb/2012 